\title{
Uncovering the Double-Edged Sword of Inter-Organisational Networks of Welfare Services: Tackling Wicked Issues in Social Work
}

\author{
Joris De Corte ${ }^{1, *}$, Bram Verschuere ${ }^{2}$, Griet Roets ${ }^{1}$ and \\ Maria De Bie ${ }^{1}$
}

\footnotetext{
${ }^{1}$ Faculty of Psychology and Educational Sciences, Department of Social Work and Social Pedagogy, Ghent University, Ghent, Belgium

${ }^{2}$ Faculty of Economics and Business Administration, Department of Public Governance, Management and Finance, Ghent University, Ghent, Belgium

*Correspondence to Joris De Corte, Faculty of Psychology and Educational Sciences, Department of Social Work and Social Pedagogy, Ghent University, Ghent, Belgium. Email: joris.decorte@ugent.be
}

\begin{abstract}
This article deals with the tendency within the field of social work practice to create inter-organisational networks for welfare provision. We highlight the opportunities that then arise for social work to tackle social exclusion, and to perform its mediating role between the public sphere of government and the private sphere of individuals and families. We argue that the advantages of inter-organisational networking and collaboration can be realised by overcoming fragmentation of care at the micro level of welfare provision to citizens, but also by using these networks as a forum for debate to challenge dominant conceptualisations of complex social problems across organisational and sectorial boundaries. However, we also point to the danger of a so-called 'network euphoria', and discuss some of the risks associated with working together through networks. Therefore, the central argument of the article implies that those involved in these networks need to develop a common framework, or value base, with reference to human rights and principles of social justice.
\end{abstract}

Keywords: Human rights, inter-professional working, multidisciplinary work, reflective practice, social exclusion

Accepted: March 2016 


\section{Introduction}

In order to realise the well-being of citizens, an ambitious pursuit of inter-organisational collaboration is recently stressed in the field of social work (Allen, 2003; Frost, 2005; Garrett, 2008; Roets et al., 2014b). In this article, we focus on the creation of inter-organisational networks between a wide range of public and private welfare actors as a means to (re-)organise welfare provision for citizens within the context of the modern welfare state (Klijn, 2008). Valuing primarily the renewed opportunities for social work, we assume that inter-organisational networks are flexible instruments to solve social problems at the micro level of individual service delivery. Moreover, we argue that these networks can become a platform for social work to perform a more active role at the macro level of social policy making by being involved in defining the social problems around which it is active.

Nevertheless, various scholars have raised questions about the actual meaning of these inter-organisational networks and the outcomes that are collectively produced for citizens (Bardach, 1998; McGuire and Agranoff, 2007; Kenis and Provan, 2009; Vangen and Huxham, 2013). Therefore, we address pertinent challenges in the implementation of these inter-organisational networks for the role of social work in the realisation of the well-being of welfare recipients.

Our main argument relates to the need for those involved in these networks to gradually develop a common framework or value base for guiding network interactions and to prevent a mere technical response to social problems. In short, this implies making reference to principles of human rights and social justice, which are articulated in the international definition of social work and can enable the incorporation of the perspective and lifeworld of those being served (Ife, 2001; Hare, 2004; Sewpaul and Jones, 2005).

In order to understand the role of social work in combining a microand macro-level approach to social problems via these inter-organisational networks, this article is structured in the following way. First, we highlight two important driving forces behind the emergence of interorganisational networks to solve social problems at the micro level of individual service delivery: the fragmentation of welfare provision in the context of the welfare state, and the increasingly complex and multidimensional character of the problems experienced by citizens.

Second, we substantiate our argument that social work, while working through networks, can create a platform or forum for being involved in the definition of social problems at the macro level of social policy making. This is related to the need for social work to perform its mediating role between the public sphere of government and the private sphere of individuals and families and for translating private needs and concerns 
into issues of broader public debate (Lorenz, 2008). Therefore, we situate the creation of networks within a broader shift from government to governance, which relates to the blurring of boundaries between the public sector and non-state actors, amongst which is social work (Pierre, 2000). Furthermore, we refer to a definition of governance networks (Sorensen and Torfing, 2005) to highlight the negotiated rationality that characterises interactions and decision-making processes within these networks.

Third, we argue that those involved in these networks need to develop a common framework, or value base, with reference to human rights and principles of social justice. This common framework can be a fertile breeding ground for social work to combine a micro- and macro-level perspective to social problems, and to ensure the deliberate incorporation of the needs, concerns and meaning-making processes of those who are served or targeted by the network.

Fourth, in the concluding section, we will rely on a metaphor of a double-edged sword to describe an inevitable field of tension when working through networks. Whereas a momentum might occur for social work to perform a mediating role and to incorporate the perspective and lifeworld of citizens, these networks might also be used as gatekeepers or holistic powers. The latter implies a narrowed focus on individual shortcomings of welfare recipients while neglecting more structural causes of social problems. As such, we argue that the tendency to create inter-organisational networks can also imply, or reinforce, a depoliticisation of social work (Specht and Courtney, 1995; Haynes and Mickelson, 1997; Allen, 2003; Stanisforth et al., 2011; Marston and McDonald, 2012; Roets et al., 2014b).

Finally, we will connect the idea of working through networks and the need for a rights-based framework, the key topics of this article, to contemporary debates for social work scholars and practitioners.

\section{Networks and service delivery to citizens}

The importance of organisational reform in the field of social work is stressed in various Western welfare states (Frost, 2005). After all, different types of welfare regimes have emerged during the second half of the twentieth century (Esping-Anderson, 1990), which were all connected with the concept of the nation state. Nevertheless, we must also point to some broader tendencies, such as globalisation of the economy, labour migration or the digitalisation of flows of information and communication that had a similar impact on all welfare regimes. This is because these processes have gradually eroded the capacity of the individual nation states to organise welfare provision to citizens (Elwood, 2006; Marramao, 2012). As such, various Western welfare states have 
struggled with the question of how to meet evolving problems experienced by citizens.

The idea of working through inter-organisational networks could then be perceived as a systemic move that offers a potential solution to the historical lack of communication and coordination between welfare institutions within the differentiated structure of the welfare system' (Allen, 2003, p. 289). This fragmentation implies that citizens might encounter substantial obstacles or thresholds at the supply side of welfare provision, which prevent them of benefiting from high-quality social services (Ellis et al., 1999). The latter could be related to the perpetuation of the historical fragmentation of care in separate sectors (Allen, 2003; Andrews and Entwistle, 2010). This bifurcation gave rise to the development of relatively autonomous policy domains, such as 'housing', 'disability care', 'mental health care', etc., which became subject to different regulations that were not necessarily complementary to one another.

Moreover, many scholars have already pointed to the increasingly complex and multidimensional character of social problems in contemporary Western welfare states and the less predictable nature of the solutions that could be provided to respond to these challenges (Clarke and Stewart, 1997; Ferlie et al., 2011). They refer to this phenomenon as so-called 'wicked issues' (Rittel and Webber, 1973), which cut across a diversity of service areas and policy domains and are too complex to be dealt with by single welfare organisations. Hence, knowledge and resources to produce an adaptive response to these wicked issues are spread across many different entities in welfare provision (Provan and Lemaire, 2012).

As problems related to fragmentation of care and the multidimensional character of problems experienced by citizens will inevitably reinforce one another, large groups of citizens have faced an increased risk of falling through the cracks in welfare provision. This necessitates a more or less coordinated response in order to reach out to often vulnerable segments of the population within the welfare state.

The creation of inter-organisational networks between a wide range of public and private actors with a common stake in welfare provision is then considered as a more flexible alternative to traditional hierarchical steering mechanisms (Powell, 1990; O'Toole, 1997). Moreover, it has been argued that these networks can compensate for the insufficiencies of organising welfare provision via market-based principles, with an overriding focus on the efficient use of scarce resources (Klijn, 2007; Isset et al., 2011). The overall aim of these networks, which are often formed at the local level, is to (re)organise welfare provision for citizens by rethinking issues such as accessibility and quality of social services (Allen, 2003; Frost, 2005). Therefore, the idea of working through networks has been associated with the concept of 'collaborative advantage' (Huxham, 2003). This refers to the creation of synergies by avoiding 
overlap, filling in service gaps, making effective use of scarce resources and unlocking the benefits of comparative advantage (Vangen and Huxham, 2013).

\section{Networks as a platform for debate}

In this section, we highlight how these inter-organisational networks can create renewed opportunities for social work. Inter-organisational networking can enable social work to overcome fragmentation and specialisation of care at the micro level of individual service delivery while combining this with an increased involvement in defining social problems at the macro level of social policy making. Therefore, we situate the creation of inter-organisational networks within a broader shift from government to governance. The latter basically refers to a decline of legitimate power of the public sector and the growing involvement of nonstate actors, amongst which social work, in the implementation but also the formulation of social policies. Moreover, we will equally outline the negotiated rationality as a key characteristic of networks. This helps us to understand how social workers can alter dominant beliefs and assumptions that are present within organisations, sectors or public policies and perform their role as applied policy makers in helping to define the problems around which they are active.

\section{A paradigm shift from government to governance}

In general terms, the emergence of inter-organisational networks is at the heart of a so-called shift 'from government to governance', which has gained much research attention in Public Administration scholarship over the last two decades (Stoker, 1998). This new paradigm tends to describe more horizontally oriented relations between government and a wide range of non-state actors, amongst which is social work.

In short, governance is considered as a new process by which society is governed (Rhodes, 1997). This implies that ideas about governing society through laws and detailed regulation have been gradually replaced by a trend to involve a variety of autonomous private actors in the public policy process (Pierre, 2000; Sorensen and Torfing, 2009; Koliba et al., 2011). This shift can be linked to critical considerations about the precarious financial basis of post-war welfare states, but also to their insufficient capacity for developing more flexible responses to the increasingly complex and multidimensional character of citizens' problems. As a result, the legitimate power and authority of the public sector to make decisions in a traditional hierarchical way have declined.

Governance is then about the search for improving the coordination between this diversity of autonomous actors while using horizontal 
mechanisms that do not rely on the authority and sanctions of government (Rhodes, 1997; Peters and Pierre, 1998). Therefore, the notion of governance is extremely conjoined with the functioning of inter-organisational networks (Marcussen and Torfing, 2003), and is perceived as the process that takes place within these networks (Klijn, 2008).

Hence, this article enhances the argument that networks can be an important lever for social work to have a stake in the formulation of social policies at the macro level as well. This relates to a long-standing debate about the involvement of social work organisations in realising social change and their commitment to policy practice and advocacy activities (Kramer, 1981; Haynes, 1998; Marston and McDonald, 2012). As Marston and McDonald (2012) assert, while making an analysis of situations and social problems, the role of the social worker in the political sphere is about a political engagement towards social justice.

After all, from a historical perspective on the development of post-war welfare states throughout Western Europe, the social work profession acquired a relatively autonomous position as a mediator between the public sphere and the private sphere of individuals and families (Lorenz, 2008). This implies that social work inherently carries a double mandate of both care and control, and has to negotiate the relationship through which private needs could be transformed into issues of public concern (Jordan and Parton, 2004). This necessitates a constant reconsideration of how to establish social solidarity and to act as a mediator between the public and private spheres (Lorenz, 2008). As such, social work must not only act via concrete welfare interventions, but must also display a continuous engagement to remain sensitive for the complexity of social problems (Roose et al., 2012) and to realise social reforms through revised social policy priorities at the macro level (Hare, 2004; Marston and McDonald, 2012).

\section{Negotiated rationality within networks}

In order to fully understand the way in which social workers make sense of these macro-level practices, we must point to particular characteristics of the inter-organisational networks in which they are active. Hence, rather than considering these networks as some kind of metaphors that could refer to all kinds of collaboration between public and private sectors (Borzel, 1998; McGuire and Agranoff, 2007), we opt to define them as 'structures of interdependence involving multiple organisations or parts thereof, where one unit is not merely the formal subordinate of others in some larger hierarchical arrangement' (O'Toole, 1997, p. 45).

Furthermore, we equally make referral to the definition of a governance network provided by Sorensen and Torfing as:

... a relatively stable horizontal articulation of interdependent but operationally autonomous public and private actors, who interact 
through negotiations that involve bargaining and deliberation, which takes place within a relatively institutionalized framework of contingently articulated norms, rules and values and that is selfregulating within the limits set by external agencies and that contributes to the production of public purpose in the broad sense of visions, ideas, plans and regulations (Sorensen and Torfing, 2005, p. 197).

In our view, this definition reveals some key issues for enhancing an understanding of the mediating role of social work via these networks: the involvement of various interdependent but operationally autonomous public and private actors, the processes of bargaining and negotiation within these networks, and the development of a relatively institutionalised framework of commonly agreed values and norms.

Therefore, it can be argued that these networks are characterised by a negotiated rationality. This implies that decisions are shaped and reshaped through continued interactions between autonomously functioning organisations that share resources and bring their respective expertise to the table (Scharpf, 1997). As organisations aim to realise both their organisational objectives as well as commonly defined goals (McGuire and Agranoff, 2007), it is argued that flows of information between these parties can be enhanced (Allen, 2003).

Moreover, we argue that the mere sharing of information between the parties involved does not suffice to initiate further debates amongst them. Rather, they must develop and design a system to enhance communication, while equally safeguarding the well-being and privacy of clients (White et al., 2015). This is especially relevant as many interorganisational networks look after highly vulnerable groups of citizens (e.g. homeless people) who are confronted simultaneously with multiple problems. The development of a system to enhance communication is, however, not self-evident, but necessitates a deliberate commitment, not only from individual social workers who are active within the network, but also from their respective organisations. This should enhance the opportunity to install a shared responsibility vis-à-vis a particular social problem via these inter-organisational networks. As a result, these networks could also become platforms for mutual learning and a forum for collectively discussing social problems. In our view, this enables these actors to develop alternative explanations for social problems and even for challenging beliefs and assumptions that are present within their respective organisations and sectors. The latter could, for example, imply a reconsideration of the criteria by which access of citizens to their organisations or sectors is regulated and restricted. Hence, these joint debates, which are performed at the level of the network as a whole, will often be 'transferred' to the level of the individual network members and have an impact on the autonomy of organisations to make their own strategic organisational decisions. 
Moreover, at the level of policy making, this relates to the need for these networks to not content themselves with the mere signalling of structural deficits with regard to welfare provision to relevant policy makers at different governmental levels (Roose et al., 2012). Despite the fact that policy work is indeed a complex and very slow process, they should maintain an awareness and a commitment to translate the needs and concerns of vulnerable groups of people into real 'policy energy' (McGuire and Agranoff, 2011). This implies that solutions are formulated in a reasonable way, which could help to overcome legal or political barriers. Hence, only when recognising that there can be no certainty about how to proceed as a policy activist (Marston and McDonald, 2012), network actors will be able to keep debates open and to challenge dominant conceptualisations of a complex and wicked problems. This could be done through the cultural reframing of a social problem and by making the diversity of citizens' experiences more visible (Zuffery, 2008).

\section{Towards a common, rights-based framework for guiding network interactions}

In the previous section, we outlined opportunities of inter-organisational networks, and addressed the necessity to identify the conditions under which the benefits of inter-organisational networking can emerge in social work practices. In our view, this search equally reveals an important question about the value base, or the frame of reference, that guides network actors when they collaborate across organisational, sectorial and public-private boundaries in the realisation of the welfare rights of vulnerable and hard-to-reach welfare recipients.

Therefore, the starting point to address a valuable common frame of reference might be the international definition of social work, as recently formulated on the website of the International Federation of Social Workers:

\footnotetext{
Social work is a practice-based profession and an academic discipline that promotes social change and development, social cohesion, and the empowerment and liberation of people. Principles of social justice, human rights, collective responsibility and respect for diversities are central to social work. Underpinned by theories of social work, social sciences, humanities and indigenous knowledge, social work engages people and structures to address life challenges and enhance wellbeing (Hare, 2004).
}

With reference to principles of human rights, which are seen as those rights that are inherent to people's nature, and without which it is not possible to survive as human beings (Hare, 2004), social work that aims to establish a socially just society should incorporate a commitment to 
social, cultural and economic rights alongside safeguarding political and civil rights (Ife, 2001). These social rights can, however, be interpreted in various ways (Dean, 2013), and a conceptual distinction can be made between a contractarian and a solidaristic approach of these rights (Roets et al., 2014a).

Within a contractarian approach, rights have a formal character and are perceived as freedom rights or choice rights (Dean, 2014). The underlying theoretical assumptions imply that welfare rights are translated as social obligations, since the ideal citizen is the one that makes deliberate choices and displays a sufficient degree of self-responsibility (Clarke, 2005; McNay, 2009). This ideology of individual choice and opportunity implies residual social work practices, expecting that so-called responsible citizens become independent and no longer need social work (Clarke, 2005). From this perspective, professionals promote and empower people and communities to solve and cure their own problems (Lorenz, 2013).

In that vein, it might be necessary to pursue inter-organisational networking from an interpretation of welfare rights as solidaristic. From a solidaristic perspective, rights are more substantive and are conceived as entitlement rights or benefit rights (Dean, 2014), which are thought of in an optimal sense as that what is required not only to survive, but in order to flourish as fully fledged human beings (Dean, 2014). In practice, welfare rights may be construed through negotiation in social relationships. As such, a thick understanding of welfare rights also embraces the social context that sustains our human dignity, or our need to flourish (Dean, 2010).

A solidaristic understanding of rights is therefore in line with an inclusive understanding of the welfare dependency of citizens (Fraser and Gordon, 1994), grounded in the relational conditions of everyday life, and rooted in social relationships which are bound by mutual interdependence rather than promoting a dependency/independency dichotomy, as we need to accept that we are all necessarily dependent on others (Williams, 1999). This refers to a notion of unconditional welfare rights, which implies that every citizen in our society has the right to human flourishing (Dean, 2010), experiencing a sense of belonging as a member of society (Lister, 2007).

Hence, starting from the aim of installing a shared responsibility vis-àvis a commonly agreed target group or social problem, a momentum might occur for welfare organisations who are involved in inter-organisational networking in dealing collectively with social problems by pulling down organisational and sectorial barriers. Their interpretations of welfare rights, in a solidaristic sense, may be contradictory, but this might give a solid underpinning for discussing and defining these social problems and translating them into political claims vis-à-vis policy makers. Moreover, new interpretations could be collectively developed while 
being the subject of productive debate (Kaneko and Imai, 1987; Powell, 1990). Welfare rights might then be constituted through revealing a plurality and diversity of concerns (Biesta, 2011; Roets et al., 2014a).

This can be done through an open-ended and dialogical process of negotiation and learning in which the targeted individual, social workers and other professionals are involved and could speak out for themselves (Grunwald and Thiersch, 2009). As a result, the actual meaning and impact of social work cannot be predefined, but must be realised over and over again in everyday practices, including those arising from working through inter-organisational networks. This is mainly because every answer to social problems will remain incomplete as it inevitably opens up new opportunities, questions and limitations. As such, we argue that social work must attempt to embrace ambiguity as a core element of the social work's profession by remaining sensitive to this complexity, and by engaging with broader public debates on these social problems (Roose et al., 2012).

In sum, we believe that inter-organisational networks, due to their negotiated rationality and horizontal relations, can function as forums for a collective debate about how to define social problems and establish a commonly agreed vision only if the realisation of welfare rights is considered from a solidaristic point of view. Moreover, networks might also create a platform to implement this shared vision, and to raise strong collective claims with the aim of realising social change in government policies, by functioning as watchdogs on behalf of the vulnerable groups they represent (Verschuere and De Corte, 2015).

\section{Concluding reflections}

\section{About inter-organisational networks as a double-edged sword}

As outlined in the introduction to this article, we rely on a metaphor of a double-edged sword to get a grip on the challenges and tensions for social work when working through inter-organisational networks.

As extensively argued throughout this article, these networks might offer renewed opportunities for social work to perform a mediating role between the public sphere of government and the private sphere of individuals and families (Lorenz, 2008). Hence, at regular points in time, a momentum might occur via this inter-organisational collaboration to combine a micro- and macro-level perspective on social problems. This implies recurrent attempts to translate private needs and concerns of individuals into issues of public concern and debate. Therefore, we stressed the importance for those involved in these networks to gradually develop a common and rights-based approach to guide their interactions and decision-making processes. This should ensure that the needs, 
concerns and meaning making of welfare recipients provide a basis for a further dialogue between social workers and clients when implementing and/or developing social policies via inter-organisational networks.

Nevertheless, we should also remain aware of the risk of developing a rather technical and controlling approach vis-à-vis welfare recipients when working through networks. This implies a narrowed focus on individual shortcomings of welfare recipients while neglecting more structural causes of social problems. This dynamic refers to a fundamentally different conceptualisation of working through networks and is diametrically opposite to the abovementioned rights-based approach. As such, it should be acknowledged that the tendency to create inter-organisational networks can even imply, or reinforce, a de-politicisation of social work (Specht and Courtney, 1995; Haynes and Mickelson, 1997; Allen, 2003; Stanisforth et al., 2011; Marston and McDonald, 2012; Roets et al., 2014b).

In essence, inter-organisational networks can be used as gate-keepers to regulate or restrict access of welfare recipients to the services of the organisations that join forces (Maeseele, 2012). In our view, this stems from a rational-technical approach to social problems with the aim of making social work more effective in dealing with risks and uncertainties (Healy, 2002; Tsui and Cheung, 2004; Lorenz, 2005; Otto et al., 2009; Saenz de Ugarte and Martin-Aranaga, 2011) that has been mainly associated with an increased focus on managerial-driven performance systems. These managerial demands facilitate a rationally and efficiently integrated supply of services, which can result in a de-personalised approach that emphasises the functional management of cases (Roets et al., 2014b). This focus on pre-structured and measurable outcomes might, however, diminish the ability or willingness to deal with the concerns of welfare recipients that are sometimes highly complex and rather unpredictable (Hood, 2014).

As such, we acknowledge that organising welfare provision for vulnerable groups of citizens should not only be guided or steered by the desire to realise more effective welfare services, but should also embrace the specificity of interests, aspirations and concerns of welfare recipients (Dean and Melrose, 1996). Based on research about inter-organisational networks and their attempt to deal with the 'wicked issue' of homelessness, for example, it was shown that homeless people are expected to express their willingness and motivation to (learn to) behave as (self-)responsible citizens as a condition to make use of all the welfare services involved in these inter-organisational networks (Maeseele, 2012). Here, the needs of welfare recipients are easily interpreted without questioning their lifeworld in an attempt to resonate with their agency and meaning making (Grunwald and Thiersch, 2009).

Furthermore, according to Allen (2003), these highly integrated networks can even operate as holistic powers that 'see everything', 'know 
everything' and 'do everything', and therefore discipline and control every aspect of welfare recipients' lives. As these holistic powers tend to be considered as infallible, there is a risk of blaming the failings of the system supposedly designed to help them on individual welfare recipients who refuse to subject themselves to the social obligations and requirements of welfare services (see Frost, 2005; Dwyer et al., 2015). Some researchers have even argued that the shift towards an increased coordination and networking of welfare services may be both politically and theoretically undesirable, arguing that 'such a shift is not to be supported as it increases the surveillance and control' over individual welfare recipients' lives (Frost, 2005, p. 19).

\section{About the transient nature of inter-organisational networks}

This conclusion about the opportunities but also drawbacks of working together via inter-organisational networks is also important against the background of the often transient nature of networks. Whereas the creation of some networks is mandated or regulated by government, others emerge from the voluntary commitment of worried and engaged social workers themselves (Marcussen and Torfing, 2003). Nevertheless, the long-term survival of a bottom-up network could be severely hampered due to changes in the composition of the network or altering priorities of its members. Hence, although these networks can be valuable and highly flexible instruments for discussing or responding to complex needs, they can also become a 'flash practice' (De Corte, 2015). This implies that the ambition to create a network might firmly ignite but quickly extinguishes afterwards. This could be the case as network members are confronted with inevitable obstacles (e.g. varying organisational cultures and legislation, the absence of trust, leadership or resources, etc.) related to collaboration via networks (Vangen and Huxham, 2013). Moreover, the mere fact of working together, or having worked together, might also pull the wool over the eyes of those involved and reduce the sense of urgency to initiate necessary further steps or debates with regard to a particular social problem.

\section{About the need to evaluate network effectiveness}

As a final remark, we state that those who are involved in networks must then focus on the complex, but indispensable, process of continuously evaluating the outcomes that are collectively produced for citizens via these networks. Hence, as networks are considered as goal-oriented structures, which implies that participants aim to realise both their organisational objectives as well as commonly defined goals (McGuire 
and Agranoff, 2007), we must pay thorough attention to the evaluation of the actual outcomes that are produced via these networks. Still, there appeared to be opposing views about how to perform this evaluation because various stakeholders might lay a claim to the network (Klijn, 2007). After all, there could be a question of for whom the network is effective (Provan and Kenis, 2007).

We acknowledge that network effectiveness must be considered as a multidimensional variable (Provan and Milward, 2001; Provan and Kenis, 2007; Klijn, 2007; Cepiku, 2013) that could be assessed at different, but interdependent, levels of analysis. For the purpose of this article, we might then refer to a rather ideal-typical position in which a distinction is made between effectiveness at the organisational level and at the community level.

At the organisational level, network effectiveness is then primarily about the benefits for each organisation that (voluntarily) invests some of its time and resources on behalf of a shared objective. This implies that network actors are at least party driven by a self-interest to acquire or secure additional resources (monies, expertise, etc.), to reduce their organisational costs or to ameliorate their status as a reliable and legitimate partner (Provan and Milward, 2001).

At the community level, however, networks are primarily considered as service-delivering vehicles that provide value to local communities and individual citizens in ways that could have not been achieved through uncoordinated provision of services by fragmented and fully autonomous agencies (Provan and Milward, 1995, 2001; Huxham, 2003).

Nevertheless, this evaluation of network effectiveness at the community level could be conducted from differing perspectives as well. This is because multiple criteria could be used to rely on to perform this evaluation. As such, we agree that any decision about these criteria is indeed a normative decision as there is no scientific way to judge whether one criterion is 'better' than another in assessing the effectiveness of the network (Kenis and Provan, 2009). In this article, we make a distinction between an instrumental logic and a client-centred approach, which is strongly linked to a rights-based framework for guiding network interactions.

From an instrumental logic, the focus is put on the efficient use of scarce resources, which relate to ideas about managerialism, performance measurement and the development of a qualitative but also prestructured supply (McGuire, 2002; Rodriguez et al., 2007; McGuire and Agranoff, 2011; Roets et al., 2014a). Although all network members could act efficiently and provide high-performance services themselves, there might still be groups that are left un-served by the totality of network members (McGuire and Agranoff, 2007).

From a client-centred logic, it is therefore required to 'better' take into account the perspectives, needs and concerns of those being served 
and targeted by the network (see e.g. Roets et al., 2014b) with the aim of coping with the complex and often unpredictable character of demands made by citizens (Roose and De Bie, 2003; Grunwald and Thiersch, 2009; Roets et al., 2014a).

In sum, whereas the effectiveness at the community level is of particular relevance for this article, the focus on the actual outcomes that are produced for clients might be hampered in a two-fold way: there is the field of tension between effectiveness at the community level and at the organisational level, but also a tension between an instrumental and a client-centred perspective to distil concrete criteria to perform the evaluation.

\section{References}

Allen, C. (2003) 'Desperately seeking fusion: On "joined-up thinking”, "holistic practice" and the new economy of welfare professional power', British Journal of Sociology, 54(2), pp. 287-306.

Andrews, R. and Entwistle, T. (2010) 'Does cross-sectoral partnership deliver? An empirical exploration of public sector effectiveness, efficiency and equity', Journal of Public Administration Research and Theory, 20, pp. 679-701.

Bardach, E. (1998) Getting Agencies to Work Together: the Practice and Theory of Managerial Craftsmanship, Washington, DC, Brookings Institution Press.

Biesta, G. (2011) Learning Democracy in School and Society, Rotterdam/Boston/ Taipei, Sense Publishers.

Borzel, T. (1998) 'Organizing Babylon: On the different conceptions of policy networks', Public Administration, 76(2), pp. 253-73.

Cepiku, D. (2013) 'Network performance: Toward a dynamic multidimensional perspective', in M., Mandell, R., Keast and R. Agranoff (eds), Network Theory in the Public Sector: Building New Theoretical Frameworks, New York: Taylor and Francis.

Clarke, J. (2005) 'New Labour's citizens: Activated, empowered, responsibilized, abandoned?', Critical Social Policy, 25(4), pp. 447-63.

Clarke, M. and Stewart, J. (1997) Handling the Wicked Issues: A Challenge for Government, Birmingham, UK, University of Birmingham, Institute of Local Government Studies.

De Corte, J. (2015) 'Local social policy and accessible social service delivery: A study of the relationships between local governments and private nonprofit organisations', doctoral research dissertation, Department of Social Work and Social Pedagogy, Ghent University.

Dean, H. (2010) Understanding Human Need, Bristol, The Policy Press.

Dean, H. (2013) 'The translation of needs into rights: Reconceptualizing social citizenship as a global phenomenon', International Journal of Social Welfare, 22(1), pp. 32-49.

Dean, H. (2014) 'A post-Marshallian conception of global social citizenship', in E. F., Isin and P., Nyers (eds), Routledge Handbook of Global Citizenship Studies, Abingdon, UK, and New York, Routledge. 
Dean, H. and Melrose, M. (1996) 'Unraveling citizenship: The significance of social security benefit fraud', Critical Social Policy, 25(4), pp. 3-31.

Dwyer P. J., Bowpitt G., Sundin, E. and Weinstein, M. (2015) 'Rights, responsibilities and refusals: Homelessness policy and the exclusion of single homeless people with complex needs', Critical Social Policy, 35(1), pp. 3-23.

Ellis, K., Davis, A. and Rummery, K. (1999) 'Needs assessment, street-level bureaucracy and the new community care', Social Policy \& Administration, 33(3), pp. 262-80.

Elwood, S. (2006) 'Critical issues in participatory GIS: Deconstructions, reconstructions, and new research directions', Transactions in GIS, 10(5), pp. 693-708.

Esping-Andersen, G. (1990) The Three Worlds of Welfare Capitalism, Princeton, NJ, Princeton University Press.

Ferlie, E., Fitzgerald, L., McGivern, G., Dopson, S. and Bennett, C. (2011) 'Public policy networks and wicked problems: A nascent solution?', Public Administration, 89(2), pp. 307-24.

Fraser, N. and Gordon, L. (1994) 'Dependency demystified: Inscriptions of power in a keyword of the welfare state', Social Politics, 1(1), pp. 4-31.

Frost, N. (2005) 'Professionalism, partnership and joined-up thinking: A research review of front-line working with children and families', Research in Practice, available online at www.rip.org.uk.

Garrett, P. M. (2008) 'How to be modern: New Labour's neoliberal modernity and the Change for Children Programme', British Journal of Social Work, 38(2), pp. 270-89.

Grunwald, K. and Thiersch, H. (2009) 'The concept of the "lifeworld orientation" for social work and social care', Journal of Social Work Practice, 23(2), pp. 131-46.

Hare, I. (2004) 'Defining social work for the 21st century: The International Federation of Social Workers' revised definition of social work', International Social Work, 47(3), pp. 407-24.

Haynes, K. S. (1998) 'The one hundred year debate: Social reform vs. individual treatment', Social Work, 43(6), pp. 501-9.

Haynes, K. S. and Mickelson, J. S. (1997) Affecting Change: Social Workers in the Political Arena, White Plains, NY, Addison Wesley Longman.

Healy, K. (2002) 'Managing human services in a market environment: What role for social workers?', British Journal of Social Work, 32, pp. 527-40.

Hood, R. (2014) 'Complexity and integrated working in children's services', British Journal of Social Work, 44(2), pp. 27-43.

Huxham, C. (2003) 'Theorizing collaborative practice', Public Management Review, 5(3), pp. 401-23.

Ife, J. (2001) 'Local and global practice: Relocating social work as a human rights profession in the new global order', European Journal of Social Work, 4(1), pp. $5-15$.

Isset, K. R., Mergel, I. A., LeRoux, K., Mischen, P. A. and Rethemeyer, R. K. (2011) 'Networks in public administration scholarship: Understanding where we are and where we need to go', Journal of Public Administration Research and Theory, 21(1), pp. 157-73.

Jordan, B. and Parton, N. (2004) 'Social work, the public sphere and civil society', in R., Lovelock, K., Lyons and J., Powell (eds), Reflecting on Social Work: Discipline and Profession, Farnham, UK, Ashgate, pp. 20-36. 
Kaneko, I. and Imai, K. (1987) 'A network view on the firm', paper presented at the first Hitotsubashi Stanford Conference.

Kenis, P. and Provan, K. G. (2009) 'Towards an exogenous theory of public network performance', Public Administration, 87(3), pp. 440-56.

Klijn, E.-H. (2007) 'Networks and inter-organizational management: Challenging, steering, evaluation and the role of public actors in public management', in E., Ferlie, L. E., Lynn and C., Pollitt (eds), The Oxford Handbook of Public Management, Oxford, Oxford University Press.

Klijn, E.-H. (2008) 'Governance and governance networks in Europe: An assessment of ten years of research on the theme', Public Management Review, 10(4), pp. $505-25$.

Koliba, C., Meek, J. W. and Zia, A. (2011) Governance Networks in Public Administration and Public Policy, Boca Ranton, CRC Press, Taylor and Francis Group.

Kramer, R. M. (1981) Voluntary Agencies in the Welfare State, Berkeley, CA, University of California Press.

Lister, R. (2007) 'Inclusive citizenship: Realizing the potential', Citizenship Studies, 11(1), pp. 49-61.

Lorenz, W. (2005) 'Social work and a new social order: Challenging neo-liberalism's erosion of solidarity', Social Work \& Society, 3(1), pp. 93-101.

Lorenz, W. (2008) 'Towards a European model of social work', Australian Social Work, 61(1), pp. 7-24.

Lorenz, W. (2013) 'Social services and their educational mandate in the modern nation state', in G., Biesta, M. De Bie and D., Wildemeersch (eds), Civic Learning, Democratic Citizenship and the Public Sphere, Dordrecht, Springer.

Maeseele, T. (2012) 'From charity to welfare rights? A study of social care practices', doctoral research dissertation, Department of Social Welfare Studies, Ghent University.

Marcussen, M. and Torfing, J. (2003) Grasping Governance Networks, Centre for Democratic Network Governance, Roskilde University, Working Paper 2003, 5.

Marramao, G. (2012) The Western Passage: Philosophy after the Age of the NationState, London and New York, Verso.

Marston, G. and McDonald, C. (2012) 'Getting beyond "heroic agency" in conceptualizing social workers as policy actors in the twenty-first century', British Journal of Social Work, Advance Access published May 24, 2012, 10.1093/bjsw/ bcs062.

McGuire, M. (2002) 'Managing networks: Propositions of what managers do and why they do it', Public Administration Review, 62(5), pp. 599-609.

McGuire, M. and Agranoff, R. (2007) 'Answering the big questions, asking the bigger questions: Expanding the public network management empirical research agenda', paper prepared for the 9th Public Management Research Conference, Tucson, Arizona, 25-27 October 2007.

McGuire, M. and Agranoff, R. (2011) 'The limitations of public management networks', Public Administration, 89(2), pp. 265-84.

McNay, L. (2009) 'Self as enterprise: Dilemmas of control and resistance in Foucault's The Birth of Biopolitics', Theory, Culture \& Society, 26(6), pp. $55-77$.

O’Toole, L. J. (1997) 'Treating networks seriously: Practical and research-based agendas in public administration', Public Administration Review, 57, pp. 45-52. 
Otto, H.-U., Polutta, A. and Ziegler, H. (2009) Evidence-Based Practice: Modernising the Knowledge Base of Social Work, Leverkusen/Opladen, Barbara Budrich.

Peters, G. and Pierre, J. (1998) 'Governance without government? Rethinking public administration', Journal of Public Administration Research and Theory, 8(2), pp. 223-43.

Pierre, J. (2000) Debating Governance: Authority, Steering, and Democracy, Oxford, Oxford University Press.

Powell, W. (1990) 'Neither market nor hierarchy: Network forms of organization', Research in Organizational Behavior, 12, pp. 295-336.

Provan, K.G. and Kenis, P. (2007) 'Modes of network governance: Structure, management, and effectiveness', Journal of Public Administration Research, 18, pp. 229-52.

Provan, K. G. and Lemaire, R. H. (2012) 'Core concepts and key ideas for understanding public sector organizational networks: Using research to inform scholarship and practice', Public Administration Review, 72, pp. 638-48.

Provan, K. G. and Milward, H. B. (1995) 'A preliminary theory of interorganizational effectiveness: A comparative study of four community mental health systems', Administrative Science Quarterly, 40, pp. 1-33.

Provan, K. G. and Milward, H. B. (2001) 'Do networks really work? A framework for evaluating public sector organizational networks', Public Administration Review, 61, pp. 414-23.

Rhodes, R. A. W. (1997) Understanding Governance, Buckingham, Open University Press.

Rittel, H. W. J. and Webber, M. (1973) 'Dilemmas in general theory of planning', Policy Sciences, 4, pp. 155-69.

Rodriguez, C., Langley, A., Beland, F. and Denis, J.-L. (2007) 'Governance, power, and mandated collaboration in an interorganizational network', Administration and Society, 39(2), pp. 150-93.

Roets, G., Dean, H. and Bouverne-De Bie, M. (2014a) 'Disability rights and disability studies in social work: Uncovering different interpretations of rights and needs of people with learning disabilities in social work practice', in F., Kessl, W., Lorenz and H.-U., Otto (eds), European Social Work: A Compendium, LeverkusenOpladen, Barbara Budrich Publisher.

Roets, G., Roose, R., Schiettecat, T. and Vandenbroeck, M. (2014b) 'Reconstructing the foundations of joined-up working: From organizational reform towards a joint engagement of child and family services', British Journal of Social Work Advance Access published November 5, 2014, 10.1093/bjsw/bcu121.

Roose, R. and Bouverne-De Bie, M. (2003) 'From participative research to participative practice: A study in youth care', Journal of Community and Applied Social Psychology, 13(6), pp. 475-85.

Roose, R., Roets, G. and Bouverne-De Bie, M. (2012) 'Irony and social work: In search of the happy Sisyphus', British Journal of Social Work, 42, pp. 1592-607.

Saenz de Ugarte, L. and Martin-Aranaga, I. (2011) 'Social work and risk society: The need for shared social responsibility', European Journal of Social Work, 14(4), pp. 447-62.

Scharpf, F. (1997) Games Real Actors Play: Actor-Centered Institutionalism in Policy Research, Boulder, Westview. 
Sewpaul, V. and Jones, D. (2005) 'Global standards for the education and training of the social work profession', International Journal of Social Welfare, 14(3), pp. 218-30.

Sorensen, E. and Torfing, J. (2005) 'The democratic anchorage of governance networks', Scandinavian Political Studies, 28(3), pp. 195-218.

Sorensen, E. and Torfing, J. (2009) 'Making governance networks effective and democratic through metagovernance', Public Administration, 87(2), pp. 234-58.

Specht, M. E. and Courtney, H. (1995) Unfaithful Angels: How Social Work Has Abandoned Its Mission, Winnipeg, Free Press.

Stanisforth, B., Fouché, C. and O'Brien, M. (2011) 'Still doing what we do: Defining social work in the 21st Century', Journal of Social Work, 11(2), pp. 191-208.

Stoker, G. (1998) 'Governance as theory: Five propositions', International Social Science Journal, 50(155), pp. 17-28.

Tsui, M.-S. and Cheung, F. C. H. (2004) 'Gone with the wind: The impact of managerialism on human services', British Journal of Social Work, 34, pp. 437-42.

Vangen, S. and Huxham, C. (2013) 'Building and using the theory of collaborative advantage', in R., Keast, M., Mandell and R., Agranoff (eds), Network Theory in the Public Sector: Building New Theoretical Frameworks, New York, Taylor and Francis.

Verschuere, B. and De Corte, J. (2015) 'Nonprofit advocacy under a third-party government regime: Cooperation or conflict?', Voluntas, 26(1), pp. 222-41.

White, S., Wastell, D., Smith, S., Hall, C., Whitaker, E., Debelle, G., Mannion, R. and Waring J. (2015) 'Improving practice in safeguarding at the interface between hospital services and children's social care: A mixed-methods case study', Health Services and Delivery Research, 3(4), pp. 1-194.

Williams, F. (1999) 'Good-enough principles for welfare', Journal of Social Policy, 28(4), pp. 667-87.

Zuffery, C. (2008) 'Responses to homelessness in Australian cities: Social worker perspectives', Australian Social Work, 61(4), pp. 357-71. 